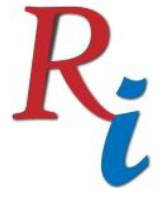

Asia Proceedings of Social Sciences

(APSS)

www.readersinsight.net/APSS

\title{
RELATIVE EFFECTS OF PROBLEM AND PROJECT-BASED \\ LEARNING TECHNIQUES ON STUDENTS ACADEMIC ACHIEVEMENT IN BUILDING TECHNOLOGY
}

\section{Yahaya, Ibn Salihu *}

Department of Technical and Engineering Education

Universiti Teknologi (UTM),

Malaysia

\section{Mohd, Safarin Nordin}

Department of Technical and Engineering Education

Universiti Teknologi (UTM),

Malaysia

*Corrosponding author's Email: yibnsalihu@ gmail.com

Author's Biography

Yahaya Ibn Salihu, was born in 1972 in Bida, Niger state, Nigeria and attended the Federal University of Technoly, Minna, University of Nigeria, Nsukka for his first and second Degrees. He is currently a Doctoral student at the Universiti Teknologi, Mlaaysia. He is a Lecturer in the Department of Building Technology Education, School of Secondary Education (Technical), Federal College of Education (Technical), Bichi, Kano, Nigeria.

Peer-review under responsibility of $3^{\text {rd }}$ Asia International Multidisciplanry Conference 2019 editorial board (http://www.utm.my/asia/our-team/) (C) 2019 Published by Readers Insight Publisher, lat 306 Savoy Residencia, Block 3 F11/1,44000 Islamabad. Pakistan,

info@ readersinsight.net This is an open access article under the CC BY-NC-ND license (http://creativecommons.org/licenses/by-nc-nd/4.0/). 


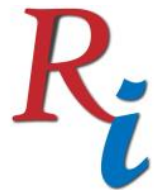

Asia Proceedings of Social Sciences

(APSS)

www.readersinsight.net/APSS

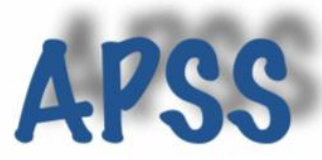

\section{Rese a r ch H i g h I igh t s}

The study compared the mean achievement scores of students exposed to problem-based learning and project-based learning against those exposed to conventional lecturer method in Building Technology achievement test. The study examined the effects of gender on students' academic achievement with respect to the treatments (teaching methods). The study proposed two hypotheses and results indicated there was significant difference in the mean ratings of students exposed to problem-based learning, problem-based learning and those exposed to conventional lecturer method. The result of hypothesis tested further revealed that gender had no significant effects on achievement of students.

\section{Research Objectives}

The study investigated relative effects of problem and project-based learning techniques on students' academic achievement in Building Technology. Specifically, the study compared the mean achievement scores of students exposed to problem-based learning and project-based learning against those exposed to conventional lecturer method in Building Technology achievement test. In addition, the study examined the effects of gender on students' academic achievement with respect to the treatments (teaching methods).

\section{Methodology}

Quasi-experimental research design was adopted to carry out the study. Quasi-experimental research design is pre-test, post-test, non-equivalent control group design. Gall Gall and Borg (2007) described quasi-experimental research design as that design that permits the use of intact classes. The research was carried out in North-central geopolitical zone of Nigeria comprising six states which include: Kogi, Niger, Benue, Kwara, Plateau, Nassarawa and the Federal Capital Territory. Three states (Niger, Kogi and Plateau) were randomly selected out the existing six states in North-central Nigeria. From the three selected states, the three colleges of education that offer Building Technology were sampled with one college of education from each of the three selected states. Hence, the three colleges of education selected are Niger State College of Education, Minna with 47 Building Technology students; Federal College of Education, Pankshin, Plateau State with 56 Building Technology students and Kogi State College of Education, Ankpa with 45 Building Technology students. Therefore, the sample for the study was 148 students of Building Technology for 2017/2018 academic session. The assignment of the classes to teaching methods was done through simple balloting. Hence, Federal College of Education, Pankshin with 56 students of Building Technology was assigned to problem-based learning (PrbL), Niger State College of Education, Minna with 47 students of Building Technology was assigned to project-based learning (PrjL) while Kogi State College of Education, Ankpa with 45 students of Building Technology was assigned to conventional lecture method. Data for this study were obtained with the use of Building Technology Achievement Test (BTAT) instrument containing 50 multiple choice questions. Each questions of the test instrument has four options (a), (b), (c) and (d) out of which one option is the correct answer. The instrument was content-validated by three experts and the reliability established using Kuder Richardson 21 (K-R21) which yielded a reliability coefficient of 0.83 . This suggested that the instrument was reliable for data collection for the study. Hamed (2016) affirmed that reliability coefficients range from 0.00 to 1.00 , with higher coefficients indicating higher levels of reliability. Before the commencement of the treatments, all students both in two experimental groups (PrbL and PrjL) and control group were subjected to a pre-test in 


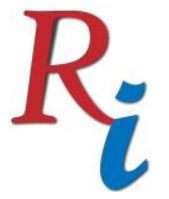

\section{Asia Proceedings of Social Sciences (APSS) \\ www.readersinsight.net/APSS}

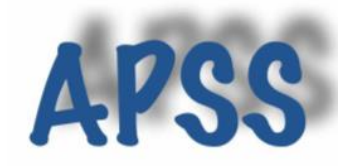

order to obtain the pre-test achievement scores. The scores obtained by students from the three groups represented their pre-test scores. Thereafter, the actual treatments began and lasted for six weeks in which students in PrbL group were taught Building Technology using Problembased learning, students in PrjL were taught Building Technology using Project-based learning while students in the control group were taught Building Technology using conventional lecture method. After the sixth week of the treatments, the post-test was administered to the students in their respective groups to obtain the post-test achievement scores. The scripts of the students were collated and marked by the researcher and the students were scored over 50 . This is because, any correct answer out of the 50 questions is 1 mark. The data collected from the three groups in the pre-test and post-test were compiled for analysis.

\section{Results}

The result showed that NCE students of Building Technology taught problem-based learning had mean achievement gain score of 18.07, students taught with project-based learning had mean achievement gain score of 20.23 while students in control group that were taught Building Technology with conventional lecture method had mean achievement gain score of 6.31. The result of Thakur and Dutt (2017) revealed that students exposed to problem-based learning method significantly showed high level of achievement motivation than the students of control group. In agreement with the findings of this study, Redmond (2014), established that project-based learning approach had significantly higher academic achievement effects on students' academic performance than those taught with traditional teaching method. Similarly, Bilqin, (2015) in a study found that students in the treatment group (project-based learning) produced better academic performance than those in control group. The results on effect of gender on the achievement scores of NCE students showed that male students taught Building Technology with problem-based learning method had mean achievement gain of 18.04 while the females taught with problem-based learning method had mean achievement gain of 18.25. On the other hand, male students taught Building Technology with project-based learning had mean achievement gain of 20.22 while the female taught with project-based learning had mean achievement gain score of 22.33 in Building Technology test. For the control group, male students taught Building Technology with conventional lecture method had mean achievement gain score of 7.11 while female students in control group had mean achievement gain score of 7.10. The study of Omaga (2017), on gender differences in electricity interest and achievement scores using problem-based learning showed no significant relationship between gender and achievement of students. The result shows that treatments (Groups) as main factor had a significant effect on students' achievement in Building Technology test. The F-calculated (Fcal) value of 103.298 and the p-value of 0.000 which is less than 0.05 level of significance indicate significant difference in the mean achievement scores of students taught with problem and project-based learning techniques and conventional lecture method based on the treatments given. For the effect of gender on academic achievement in Building Technology, the result shows that, the F-calculated value of 0.170 and p-value of 0.681 which was greater than 0.05 level of significance indicate that there was no significant difference in the mean achievement scores of male and female students in the Building Technology achievement test. The result of Murat (2015), showed no significant gender difference as project-based learning had a positive effect on both male and female students. In the same manner, Chu (2009), investigated inquiry project-based learning and found that gender (male and female) differences and academic abilities had no significant moderating effects on the learning dimensions. Interaction effects of gender and instructional techniques (Group*Gender) shows F-calculated (F-cal) value of 


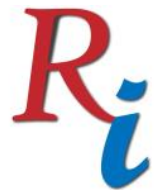

\section{Asia Proceedings of Social Sciences (APSS) \\ www.readersinsight.net/APSS}

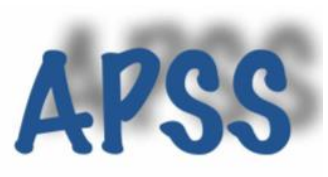

0.119 with p-value of 0.888 which is greater than 0.05 level of significance. This indicates that there was no significant interaction effect between the treatments (Groups) and gender of the students in respect to Building Technology achievement test.

\section{Findings}

The results clearly show that the use of problem and project-based learning techniques appreciably increased academic achievement of NCE students in Building Technology than using conventional lecture method for instructional delivery. Both problem and project-based learning techniques significantly increased academic achievement of male and female students in Building Technology than conventional lecture technique. The results showed that there was no significant difference between the mean achievement scores of male and female students when taught electricity using problem based learning approach. Although, students taught with project-based learning had slightly higher achievement gain score than those taught with problem-based learning.

Key words: academic achievement; building technology; lecture; problem based learnig; project based learning.

\section{References}

Bilgin, I, Karakuyu, Y and Ay Y. (2015). "The Effects of Project Based Learning on Undergraduate Students' Achievement and Self-Efficacy Beliefs towards Science Teaching”. Eurasia Journal of Mathematics, Science \& Technology Education, 11 (3): 469 - 477.

Chu, S. (2009). "Inquiry project-based learning with a partnership of three types of teachers and the school librarian". Journal of the American Society for Information Science and Technology, 60(8): 1671 - 1686, 2009.

Gall, M. D., Gall, J. P, and Borg, W. R. (2007). “Educational Research: An Introduction. (Eight Edition)”. Boston, New York: Pearson Education Inc.

Hamed, T. (2016). "Validity and Reliability of the Research Instrument; How to Test the Validation of a Questionnaire/Survey in a Research". International Journal of Academic Research in Management (IJARM), 5 (3): 28 - 36.

Murat, G. (2015). "The project-based learning approach in environmental education". International Research in Geographical and Environmental Education, 24 (2): 105 - 117.

Omaga, J. O. (2017). "Gender Differences in Electricity Interest and Achievement Scores: A case of Problem Based Learning (PBL) Approach". International Journal of Innovative Social \& Science Education Research, 5(2): $9-15$.

Redmond, K. (2014). The Effects of Project-Based Learning on Student Achievement in a Fourth Grade Classroom". An Unpublished Masters Project submitted to Department of Science Education, Montana State University Bozeman, Montana.

Thakur, P., and Dutt S. (2017). "Problem-based learning in biology: Its effect on achievement motivation of students of 9th standard". International Journal of Multidisciplinary Education and Research, 2 (2): 99 - 104. 